\title{
Eocene to Oligocene nannofossils stratigraphy and environmental conditions in Izeh Province, Zagros Basin, East Tethys
}

\author{
Saeedeh Senemari ${ }^{1 *}$ (D) and Farah Jalili ${ }^{2}$
}

\begin{abstract}
Data obtained from the calcareous nannofossils, distributed in the upper part of the Pabdeh Formation (Priabonian-Rupelian) and the lower part of the Asmari Formation (Chattian) in the Bid-Zard section, were used to investigate the Eocene to Oligocene palaeoenvironmental conditions in the southwest of Izeh, southwestern Iran (eastern Tethys). The upper part of the Pabdeh Formation was composed of shale, thin-bedded pelagic limestone and dolostone, which is disconformably overlain by the Asmari Formation. For the first time, 29 species of calcareous nannofossils belonging to 13 genera were identified in the studied section. The calcareous nannofossils in the upper part of the Pabdeh Formation indicate the Isthmolithus recurvus Zone/Sphenolithus pseudoradians Zone (combined zone), Ericsonia subdisticha Zone, Helicosphaera reticulata Zone and Sphenolithus praedistentus Zone, from the Priabonian to the Rupelian. The Sphenolithus ciperoensis Zone of the Chattian was identified in the lower part of the Asmari Formation. Calcareous nannofossil stratigraphy across the upper Eocene-Oligocene interval also reveals a disconformity at the Rupelian/Chattian transition due to a bio-event. Shallowing of the basin and environmental changes in this part of the Tethyan domain could have led to the lithostratigraphic and biostratigraphic changes. In fact, during the late Eocene to late Oligocene, marine phytoplankton was sensitive to climate changes such as decreasing temperature, as well as possibly to a nutrient increase and changes in basin depth.
\end{abstract}

Keywords: Biostratigraphy, Calcareous nannofossils, Ecological indicators, Tethys domain, Zagros, Paleogene

\section{Introduction}

Marine sediments of the Pabdeh and Asmari formations at the Eocene-Oligocene transition are one of the most important source rocks and hydrocarbon reservoirs at the margin of the Zagros Basin in southwestern Iran (Kamali et al. 2006; Bordenave and Hegre 2010). The Zagros Basin is located at the collisional zone of the Arabian Plate and Iranian Block, and includes a very thick marine sedimentary succession (Al-Husseini 2000; Lacombe and Mouthereau 2006) (Fig. 1). In fact, the Zagros Mountains of SW Iran are a part of the Alpine-

\footnotetext{
*Correspondence: s.senemari@eng.ikiu.ac.ir; senemari2004@yahoo.com 'Department of Mining, Faculty of Engineering, Imam Khomeini International University, Qazvin, Iran

Full list of author information is available at the end of the article
}

Himalayan orogenic system, which is one of the most important sedimentary areas in the world with a NWSE trend (Fig. 1b). The basin is composed of a gently folded rock succession with several stratigraphic provinces such as Lurestan, Izeh, Fars, and Khuzestan (including the Dezful Embayment) (Motiei 1994; Darvishzadeh 2003; Alavi 2004). The Pabdeh Formation was mostly deposited during the Paleocene-Oligocene and is present in all these areas in both outcrops and subsurface. After the Late Cretaceous compressive phase (Laramid phase), the sea level rose and the Zagros Basin deepened progressively during the Paleogene, which led to the deposition of the Pabdeh Formation in the deeper parts (Aghanabati 2004). Then, as the global sea level fell, the basin became shallower toward the top of the 

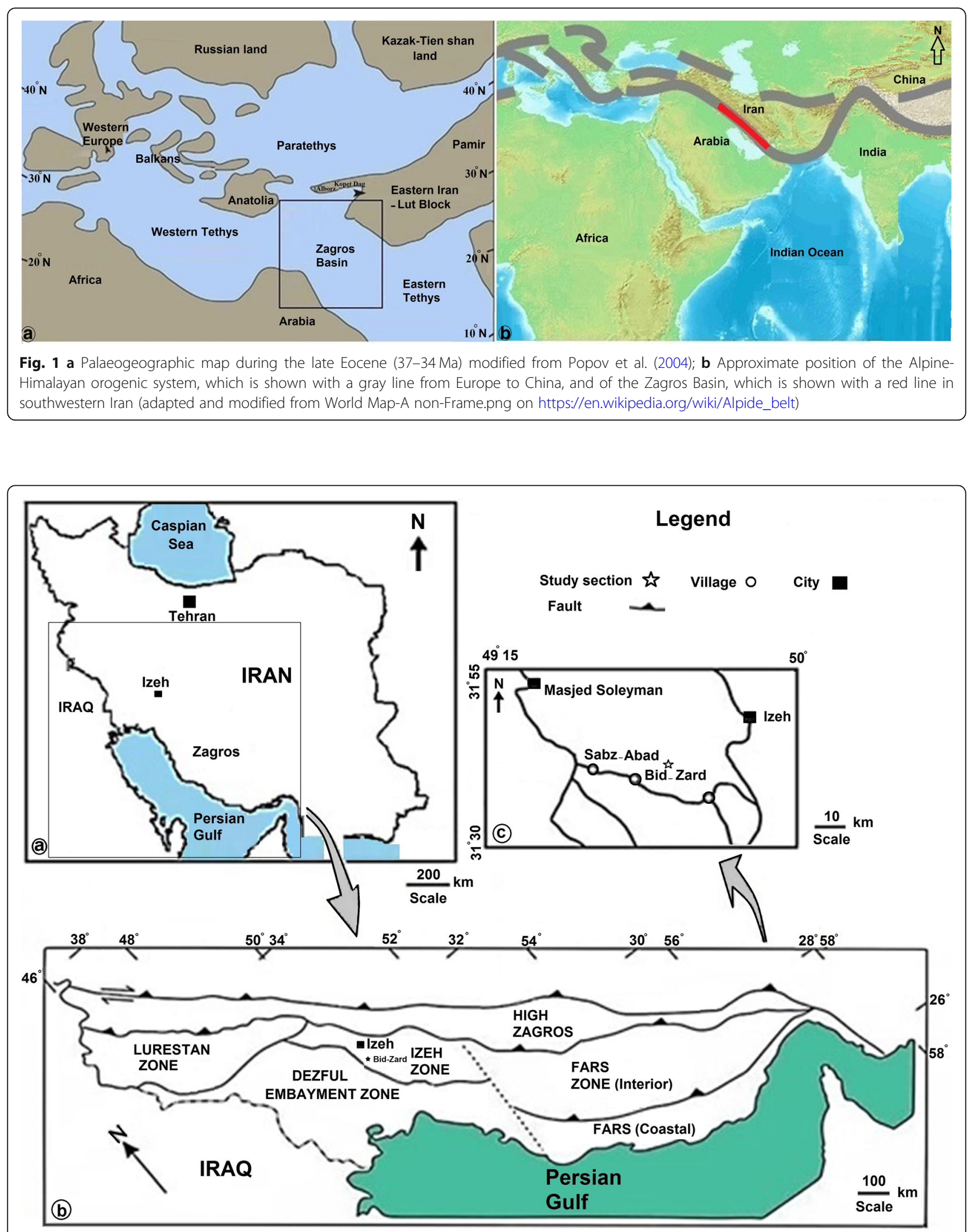

Fig. 2 a The Zagros study site locality on the Iran map; b Tectonic outline map and sub-divisions of the Zagros Basin in southwestern Iran; c Approximate geographical location of the Bid-Zard section marked with an asterisk 
Pabdeh Formation. This was followed at the top of the Pabdeh Formation by a transitional shale facies and by deposition of anhydrite of the Asmari Formation (Amin-Rasouli et al. 2012). Thus, the Pabdeh Formation is overlain by the Asmari Formation. However, disagreement still exists about whether the boundary between the Pabdeh and Asmari formations is continuous or discontinuous, as well as about the exact age of the basal anhydrite and its overlying transitional sediments in the Asmari Formation (e.g., James and Wynd 1965; Motiei 1995; Seyrafian 2000; VaziriMoghaddam et al. 2006; Amirshahkarami et al. 2007).

In recent decades, the Pabdeh Formation has been considered by most geologists as one of the important source rocks in the Zagros Basin (e.g., Amirkhani et al. 2015). Biostratigraphic studies on the Zagros Basin, especially on the Pabdeh Formation, were mostly based on foraminifera (e.g., Behbahani et al. 2010). These studies recognized a conformable boundary between the Pabdeh and Asmari formations. In addition, the Mesozoic and Cenozoic deposits in the Zagros Basin have been extensively studied using calcareous nannofossils (e.g.,
Gholami Fard 2007; Hadavi et al. 2007; Senemari 2007; Sadeghi and Hadavand Khani 2010; Khavari Khorasani et al. 2014; Senemari 2014; Senemari and Bakhshandeh 2014; Ahifar et al. 2015). This paper presents the first results of the nannofossil stratigraphy of the Pabdeh and Asmari formations.

In this study, calcareous nannofossils from the BidZard section in the Dezful Embayment Zone (Fig. 2), located about $50 \mathrm{~km}$ southwest of Izeh, are sampled and analyzed. The study region covers the area between longitudes $49^{\circ} 15^{\prime} \mathrm{E}-49^{\circ} 45^{\prime} \mathrm{E}$ and latitudes $31^{\circ} 30^{\prime} \mathrm{N}-31^{\circ} 40^{\prime}$ $\mathrm{N}$. The Bid-Zard section was sampled every 1-2 $\mathrm{m}$ from the upper part of the Pabdeh Formation and the lower part of the Asmari Formation (Fig. 3). The main objectives are to document and identify calcareous nannofossil assemblages, establish a biostratigraphic framework, and evaluate depositional/environmental conditions across the Pabdeh/Asmari boundary, in order to investigate source and reservoir rocks in southwestern Izeh. This evaluation, based on the calcareous nannofossils, highlights the significance of biological events and

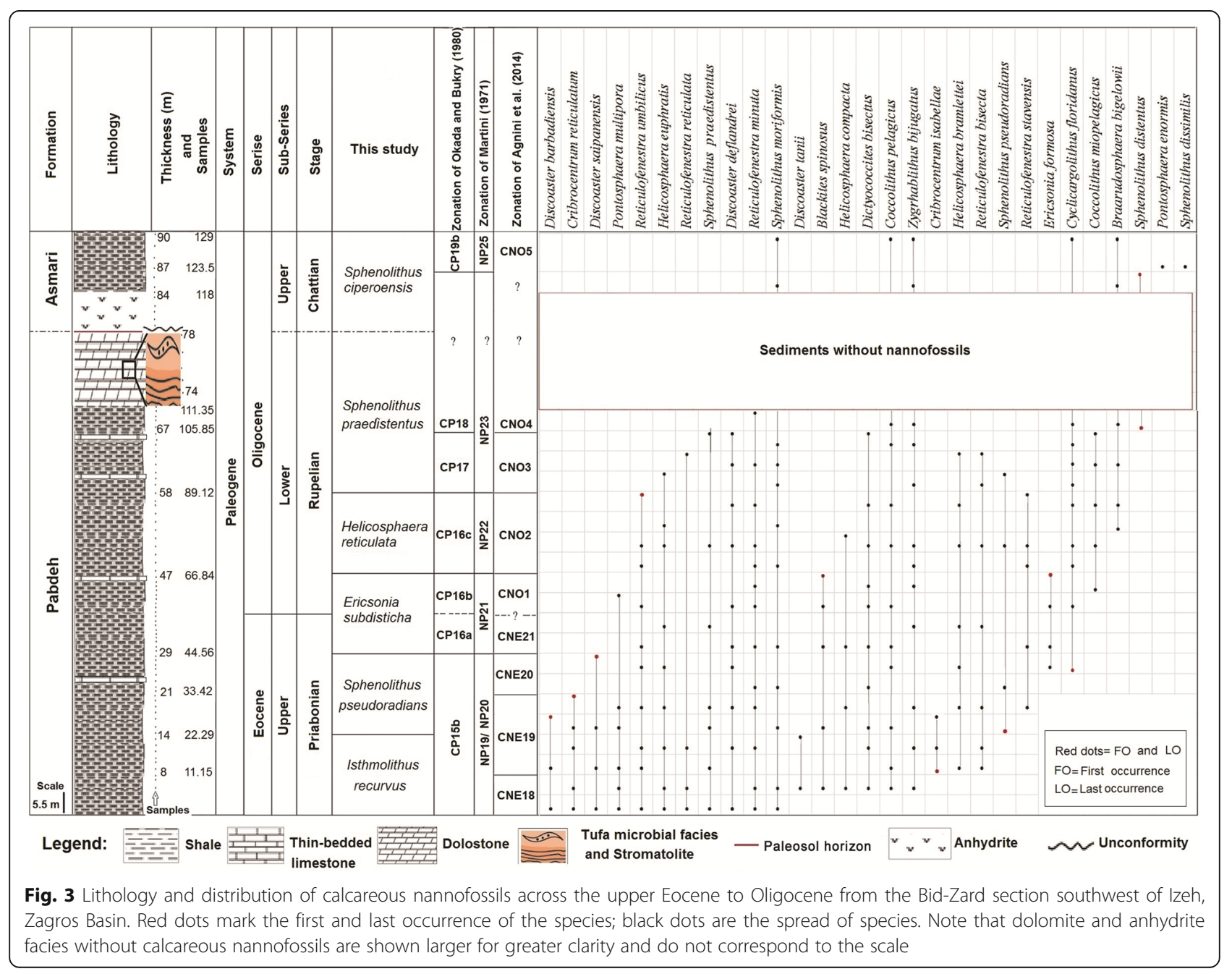


demonstrates that the boundary between the Pabdeh Formation and the Asmari Formation was discontinuous and that the water depth of the basin decreased at the end of the Rupelian.

\section{Material and methods}

The studied samples belong to the Bid-Zard section in southwestern Izeh, a 129-m-thick sedimentary succession containing the upper part of the Pabdeh Formation and the lower part of the Asmari Formation. Seventy-eight fresh rock samples from shales and thin-bedded limestones were collected for calcareous nannofossils based on lithological changes. The section was sampled at about $1-1.5 \mathrm{~m}$ intervals; combined results of every three samples are shown in Figs. 3 and 4. The upper part of the Pabdeh Formation in the section is composed of shale, thin-bedded pelagic limestone, and dolostone. The shale facies is laminated, dark-colored, rich in organic matter, and contains thin-bedded limestones. The abundance of organic matter indicates that the facies formed in the absence of oxygen. The thin-bedded pelagic limestones contain phosphate grains, glauconite, and planktonic foraminifers. Due to these features, the shale facies was inferred to have formed above the carbonate compensation depth (CCD). At the top of the Pabdeh Formation, deep pelagic dolomitic rocks (samples 73-78) were deposited including a 4.2-m-thick microbial facies and stromatolites. The microbial facies consist of dark and light as well as wavy laminae. Stromatolites also consist of dark and light layers, flat to wavy, and contain a fenestral fabric. The boundary between the Pabdeh and Asmari formations is marked by a red paleosol horizon. Subsequently, the lowest part of the Asmari Formation, mainly composed of a basal blocky anhydrite, was deposited. An about-2.45-m-thick layer of the basal anhydrite (samples 79-84) probably formed as a result of a temporary disconnection with the open sea (regression). Eventually, the deep deposits of the transitional zone of the Pabdeh and Asmari formations were formed with shale facies. In fact, during the depositional process in transitional zone following transgression, shale facies was deposited (samples 85-90) (Figs. 3 and 4). Twelve samples were also

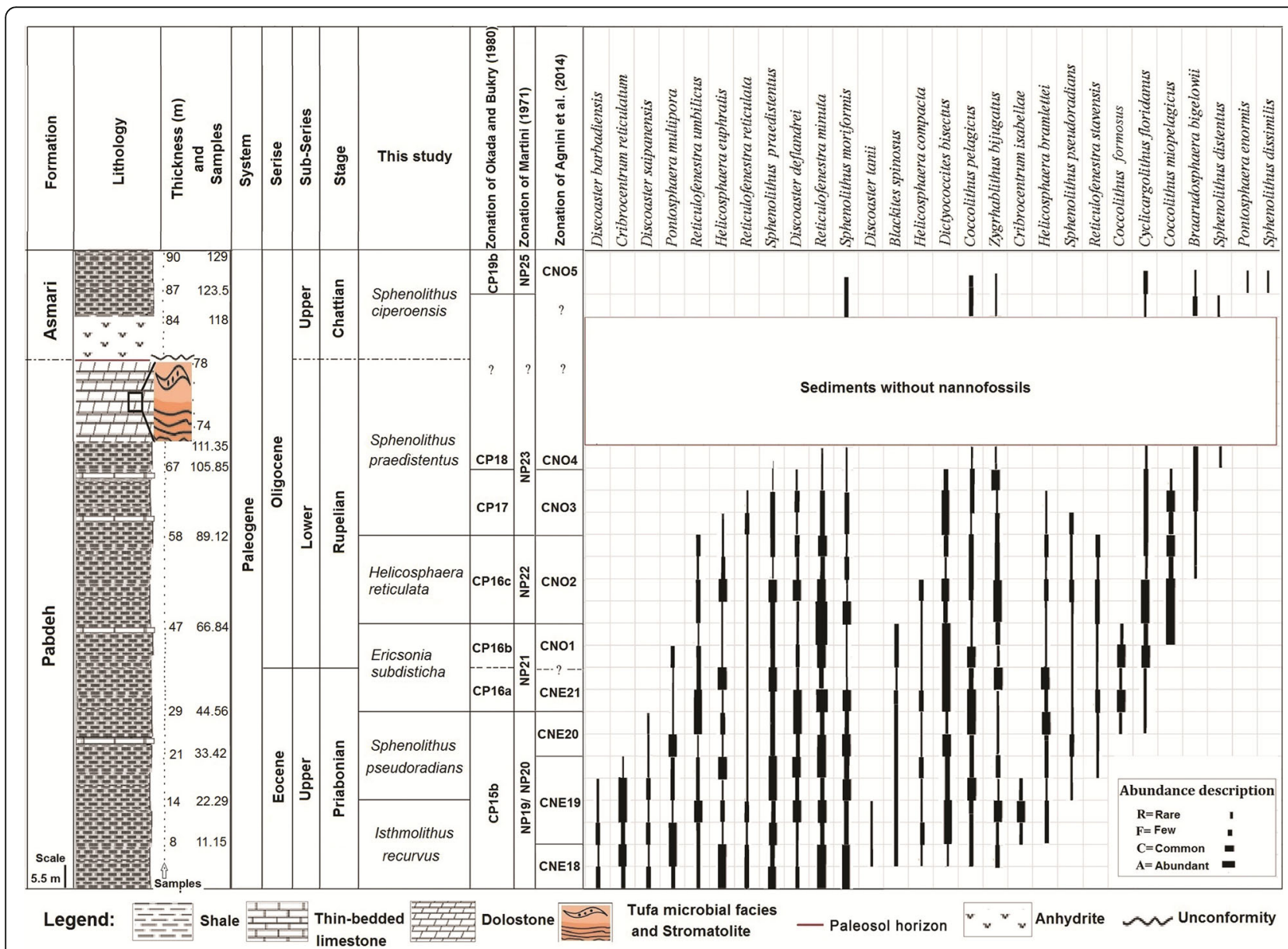

Fig. 4 Diversity and abundance of calcareous nannofossils across the upper Eocene to Oligocene from the Bid-Zard section southwest of Izeh, Zagros Basin. Note that dolomite and anhydrite facies without calcareous nannofossils are shown larger for greater clarity and do not correspond to the scale 
taken from both dolomite and anhydrite facies in the transition zone of the two formations.

Selected samples were prepared following the standard smear slide method (Bown and Young 1998). All the slides were studied under the crossed- and plane-polarized light of a BH2 Olympus microscope with 1000-fold magnification and photographed by a Canon digital camera. Palaeoenvironmental reconstruction of the section was performed based on semi-quantitative analyses of selected calcareous nannofossils. For each slide, five to seven transverse rows were counted to identify the calcareous nannofossils in order to observe changes in the assemblage of each taxon. The abundance of calcareous nannofossils (per fields of view/per FOVs) was assessed as: $\mathrm{R}=\operatorname{Rare}(1$ specimen per $11-100$ FOVs); $\mathrm{F}=$ Few (1 specimen per $2-10 \mathrm{FOVs}) ; \mathrm{C}=\mathrm{Common}$ (1-10 specimens per $1 \mathrm{FOVs}) ; \mathrm{A}=$ Abundant $(>10$ specimens per 1 FOVs). The most common species are illustrated in Fig. 5. For identification of the calcareous nannofossils, the taxonomic concepts of Perch-Nielsen (1985) and the Nannotax website (http://www.mikrotax.org/Nannotax3) were used. For biostratigraphic analysis, zonations of Martini (1971), Okada and Bukry (1980), and Agnini et al. (2014) were applied. For the Paleogene nannoplankton (NP) abbreviations of the Martini (1971) zonation were used, for Paleogene coccoliths (CP) those of the Okada and Bukry (1980) zonation, and for Eocene/Oligocene calcareous nannofossil (CNE/ CNO) those of the Agnini et al. (2014) zonation. The bioevents were delineated as the first occurrence (FO) and the last occurrence (LO) of index species.

Calcareous nannofossil taxa identified in this study (Fig. 5) are given based on Perch-Nielsen (1985) in alphabetical order as follows:

- Blackites spinosus (Deflandre and Fert 1954) Hay and Towe 1962

- Braarudosphaera bigelowii (Gran and Braarud 1935) Deflandre 1947

- Coccolithus miopelagicus Bukry 1971

- Coccolithus pelagicus (Wallich 1877) Schiller 1930

- Cribrocentrum isabellae Catanzariti, Rio and Fornaciari in Fornaciari et al. 2010

- Cribrocentrum reticulatum Perch-Nielsen 1971

- Cyclicargolithus floridanus (Roth and Hay, in Hay et al. 1967) Bukry 1971

- Dictyococcites bisectus (Hay, Mohler and Wade 1966) Bukry and Percival 1971

- Discoaster barbadiensis Tan Sin Hok 1927

- Discoaster deflandrei Bramlette and Riedel 1954

- Discoaster saipanensis Bramlette and Riedel (1954)

- Discoaster tanii Bramlette and Riedel 1954

- Ericsonia formosa (Kamptner 1963) Haq $1971=$ Coccolithus formosus (Kamptner1963) Wise 1973

- Helicosphaera bramlettei (Müller 1970) Jafar and Martini 1975
- Helicosphaera compacta Bramlette and Wilcoxon 1967

- Helicosphaera euphratis Haq 1966

- Pontosphaera enormis (Locker 1967) Perch-Nielsen 1984

- Pontosphaera multipora (Kamptner 1948 ex Deflandre in Deflandre and Fert 1954) Roth et al. 1970

- Reticulofenestra bisecta (Hay, Mohler and Wade 1966) Roth et al. 1970

- Reticulofenestra minuta Roth et al. 1970

- Reticulofenestra reticulata (Gartner and Smith 1967) Roth and Thierstein 1972

- Reticulofenestra stavensis (Levin and Joerger 1967) Varol 1989

- Reticulofenestra umbilicus (Levin 1965) Martini and Ritzkowski 1968

- Sphenolithus dissimilis Bukry and Percival 1971

- Sphenolithus distentus (Martini 1965) Bramlette and Wilcoxon 1967

- Sphenolithus moriformis (Brönnimann and Stradner 1960) Bramlette and Wilcoxon 1967

- Sphenolithus praedistentus Bramlette and Wilcoxon 1967

- Sphenolithus pseudoradians Bramlette and Wilcoxon 1967

- Zygrhablithus bijugatus (Deflandre in Deflandre and Fert 1954) Deflandre 1959

\section{Zonal biostratigraphy}

The calcareous nannofossil group is a powerful tool for studying stratigraphic correlations on a global and regional scale, and has been discussed in detail by various researchers (e.g., Martini 1971; Okada and Bukry 1980; Perch-Nielsen 1985; Gradstein et al. 2012). In the present study, lithologies of the upper part of the Pabdeh Formation and the lower part of the Asmari Formation in the Bid-Zard section were examined. A total of 13 genera and 29 species of calcareous nannofossils were identified, which are well preserved in most slides and document general changes through the section.

The zonal boundaries were determined by the comparison with the standard biozonations of Martini (1971) and Agnini et al. (2014). Accordingly, our data based on calcareous nannofossil events allow the studied section to be assigned to the NP19/NP20 combined zone to the NP25 zone, indicating a Priabonian to Chattian interval. This study also focuses on the environmental conditions of the calcareous nannofossils, which are index fossils at low latitudes during the late Eocene to late Oligocene.

Five biozones in the studied section are introduced in the following. They are equivalent to the NP19/ NP20 combined zone to NP23 zone in the upper part 

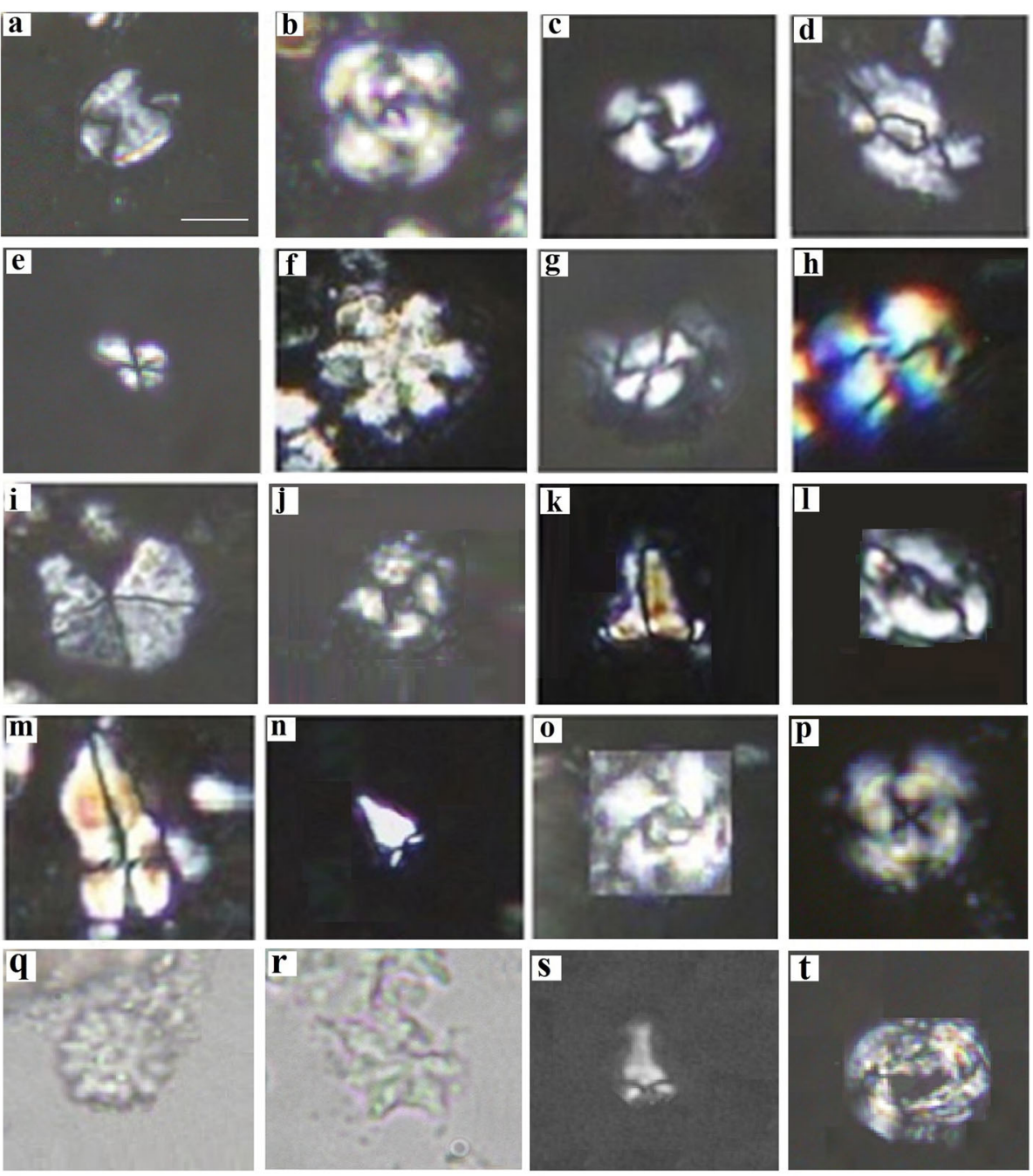

Fig. 5 Light microscope images of nannofossils from the Bid-Zard section southwest of lzeh, Zagros Basin. Taxonomic definition follows Perch-Nielsen (1985). a Pontosphaera multipora (Kamptner 1948 ex Deflandre in Deflandre and Fert 1954) Roth et al. 1970; b Cribrocentrum isabellae Catanzariti, Rio and Fornaciari in Fornaciari et al. 2010; c Cyclicargolithus floridanus (Roth and Hay, in Hay et al. 1967) Bukry 1971; d Helicosphaera euphratis Haq 1966; e Sphenolithus dissimilis Bukry and Percival 1971; f Discoaster deflandrei Bramlette and Riedel 1954; g Coccolithus pelagicus (Wallich 1877) Schiller 1930; h Dictyococcites bisectus (Hay, Mohler and Wade 1966) Bukry and Percival 1971; i Braarudosphaera bigelowii (Gran and Braarud 1935) Deflandre 1947; j Coccolithus formosus (Kamptner 1963) Wise 1973; k Zygrhablithus bijugatus (Deflandre in Deflandre and Fert 1954) Deflandre 1959; I Helicosphaera bramlettei (Müller 1970) Jafar and Martini 1975; m Sphenolithus pseudoradians Bramlette and Wilcoxon 1967; n Sphenolithus praedistentus Bramlette and Wilcoxon 1967; o-p Cribrocentrum reticulatum PerchNielsen 1971; q Discoaster barbadiensis Tan Sin Hok 1927; r Discoaster saipanensis Bramlette and Riedel (1954); s Sphenolithus distentus (Martini 1965) Bramlette and Wilcoxon 1967; t Reticulofenestra umbilicus (Levin 1965) Martini and Ritzkowski 1968. Scale bar for (a) to (t): 5 um

of the Pabdeh Formation and to the NP25 zone in the lower part of the Asmari Formation according to the Martini (1971) zonation:

\subsection{Biozones in the upper part of the Pabdeh Formation}

\subsubsection{Isthmolithus recurvus Zone/Sphenolithus} pseudoradians Zone (NP19/NP20 combined zone) - Top of CNE18, CNE19, CNE20/CP15b

The lowest nannofossil biozone recorded in this study is the Priabonian Isthmolithus recurvus Zone/Sphenolithus pseudoradians Zone (NP19/NP20 combined zone). The NP19 zone is identified from the first occurrence of Isthmolithus recurvus to the first occurrence of Sphenolithus pseudoradians in the Martini (1971) zonation. Isthmolithus recurvus was not found in the studied section, so the lower boundary of the NP19 zone has not been detected. Subsequently, the NP20 zone is defined from the first occurrence of Sphenolithus pseudoradians to the last occurrence of Discoaster saipanensis in the Martini (1971) zonation. According to Martini (1971), since the 
first occurrence of S. pseudoradians was reported differently and might not be an accurate indicator for determining the lower boundary of the NP20 zone, the NP19 zone cannot be separated clearly from the NP20 zone. Hence, the interval below the last occurrence of Discoaster saipanensis (the marker of the base of both NP21 and CP16 zones), can be defined as the NP19/NP20 combined zone or is equivalent to the CP15b subzone. In this zone, the calcareous nannofossil species are abundant and they are well-preserved. The nannofossil assemblages include Blackites spinosus, Cribrocentrum isabellae, C. reticulatum, Coccolithus pelagicus, Cyclicargolithus floridanus, Discoaster deflandrei, D. barbadiensis, D. saipanensis, Ericsonia formosa (=Coccolithus formosus), Helicosphaera bramlettei, $H$. compacta, $H$. euphratis, Pontosphaera multipora, Reticulofenestra reticulata, $R$. stavensis, $R$. umbilicus, $R$. minuta, Sphenolithus praedistentus, $S$. pseudoradians, $S$. moriformis, and Zigrhablithus bijugatus. According to the Agnini et al. (2014) zonation, the CNE18 zone is defined as the interval from the top of common Cribrocentrum erbae to the first occurrence of Cribrocentrum isabellae. In the BidZard section, the base of the CNE18 zone cannot be recognized due to the absence of Cribrocentrum erbae, but the top of the zone was determined by the first occurrence of C. isabellae (at $11.15 \mathrm{~m}$ ). The CNE19 zone is defined from the first occurrence of $C$. isabellae (at $11.15 \mathrm{~m}$ ) to the last occurrence of C. reticulatum (at $33.42 \mathrm{~m}$ ), which is restricted to the Priabonian. In addition, the CNE20 zone is defined by the last occurrence of $C$. reticulatum, a suitable index used to determine the boundary of the CNE19/CNE20 combined zone (Fornaciari et al. 2010; Agnini et al. 2011). The last occurrence of $C$. reticulatum is found at the $33.42 \mathrm{~m}$ level and the last occurrence of D. saipanensis at 44.56 $\mathrm{m}$, which respectively mark the base of the CNE21 zone and the top of the CP15b subzone in the Okada and Bukry (1980) zonation. Therefore, the NP19/NP20 combined zone corresponds to the upper part of CNE18, CNE19, CNE20, and CP15b with a thickness of $44.56 \mathrm{~m}$.

\subsubsection{Ericsonia subdisticha Zone (NP21) - CNE21-CNO1/ CP16a-CP16b}

The next nannofossil biozone recorded in the upper part of the Pabdeh Formation is the NP21 zone dated as Priabonian/Rupelian. The Ericsonia subdisticha Zone is defined as an interval from the last occurrence of Discoaster saipanensis to the last occurrence of Ericsonia formosa (=Coccolithus formosus) (Martini 1971). The last occurrence of Discoaster saipanensis and the last occurrence of Ericsonia formosa were found at $44.56 \mathrm{~m}$ and $66.84 \mathrm{~m}$, respectively. The most important nannofossil taxa of this zone belong to Coccolithus pelagicus, C. miopelagicus, C. formosus, Cyclicargolithus floridanus,
Dictyococcites bisectus, Discoaster deflandrei, Helicosphaera bramlettei, H. compacta, H. euphratis, Pontosphaera multipora, Reticulofenestra minuta, Sphenolithus moriformis and Zygrhablithus bijugatus. It should be mentioned that across this interval, the total abundance of nannofossil increased and they are wellpreserved. In the Agnini et al. (2014) zonation, the CNE21 zone is introduced as an interval from the last occurrence of Discoaster saipanensis to the first occurrence of acme Clausicoccus subdistichus. Subsequently, $\mathrm{CNO} 1$ is defined as an interval from the first occurrence of acme Clausicoccus subdistichus to the last occurrence of Ericsonia formosa (=Coccolithus formosus). In the present study, the base of the CNO1 zone cannot be defined due to the absence of $C$. subdistichus. Therefore, the CNE21/CNO1 zone boundary and the CP16a/CP16b subzone boundary are not specified. The last occurrence of E. formosa (=C. formosus), marks the top of the $\mathrm{CNO} 1$ zone and the CP16b subzone $(66.84 \mathrm{~m})$. Hence, the NP21 zone corresponds to the CNE21-CNO1 combined zones and also to the CP16a-CP16b combined subzones. The thickness of this zone is $22.28 \mathrm{~m}$.

\subsubsection{Helicosphaera reticulata Zone (NP22) - CNO2/CP16c}

The Helicosphaera reticulata Zone (NP22) is defined as the interval from the last occurrence of Ericsonia formosa (=Coccolithus formosus) to the last occurrence of Reticulofenestra umbilicus in the Martini (1971) zonation. In this study, the NP22 zone spans an interval from the last occurrence of $C$. formosus (at $66.84 \mathrm{~m}$ ) to the last occurrence of Reticulofenestra umbilicus (at $89.12 \mathrm{~m}$ ) and falls in the Rupelian (32.95-32 Ma) (Gradstein et al. 2012). According to Martini (1971), the high occurrence of $R$. umbilicus defines the base of the NP23 zone. Species identified in this biozone include Braarudosphaera bigelowii, Coccolithus pelagicus, C. miopelagicus, Cyclicargolithus floridanus, Discoaster deflandrei, Dictyococcites bisectus, Helicosphaera euphratis, H. compacta, H. bramlettei, Reticulofenestra umbilicus, $R$. minuta, Sphenolithus praedistentus, $S$. moriformis, S. pseudoradians, and Zygrhablithus bijugatus. The preservation of calcareous nannofossils in this zone is moderate to good. In the Agnini et al. (2014) zonation, the $\mathrm{CNO} 2$ and $\mathrm{CNO} 3$ zones are defined by the last occurrence of $E$. formosa $(=C$. formosus) and the last occurrence of $R$. umbilicus, which were found in the Bid-Zard section at $66.84 \mathrm{~m}$ and $89.12 \mathrm{~m}$, respectively. Therefore, the NP22 zone corresponds to the $\mathrm{CNO} 2$ zone and $\mathrm{CP} 16 \mathrm{c}$ subzone, already shown by Agnini et al. (2014). The NP22 zone reaches a thickness of $22.2 \mathrm{~m}$.

\subsubsection{Sphenolithus praedistentus Zone (NP23) - CNO3 and the lower part of CNO4/CP17 and the lower part of CP18}

The uppermost nannofossil biozone recorded in the Pabdeh Formation is the Sphenolithus praedistentus 
Zone (NP23). According to Martini (1971), the NP23 zone spans an interval from the last occurrence of Reticulofenestra umbilicus to the first occurrence of Sphenolithus ciperoensis. As mentioned above, the last occurrence of Reticulofenestra umbilicus was recorded at $89.12 \mathrm{~m}$, but the first occurrence of Sphenolithus ciperoensis was not confirmed due to the absence of all calcareous nannofossil species in the interval from $111.35 \mathrm{~m}$ to $118 \mathrm{~m}$. Nannofossils were absent from the upper part of the Pabdeh Formation composed by the tufa microbial facies, which is a bio-event that coincided with the Rupelian/Chattian interval in the studied section. Therefore, the top of NP23 zone or the transition between the Pabdeh and Asmari formations is simply lacking in nannofossils. Here, the boundary between the formations as well as the upper part of the NP23 zone and the entire NP24 zone were not determined due to the lack of index species (Fig. 3). Species such as Braarudosphaera bigelowii, Coccolithus pelagicus, C. miopelagicus, Cyclicargolithus floridanus, Discoaster deflandrei, Dictyococcites bisectus, Helicosphaera bramlettei, H. euphratis, Reticulofenestra minuta, $R$. reticulata, Sphenolithus distentus, $S$. moriformis, S. praedistentus, S. pseudoradians and Zygrhablithus bijugatus were identified in the lower part of the NP23 zone, and were moderately preserved. In the Agnini et al. (2014) zonation, the $\mathrm{CNO} 3$ zone is defined from the last occurrence of Reticulofenestra umbilicus to the first occurrence of Sphenolithus distentus. In this study, the first occurrence of $S$. distentus was recorded at $105.85 \mathrm{~m}$, so the boundaries of $\mathrm{CNO} 3 / \mathrm{CNO} 4$ and $\mathrm{CP} 17 / \mathrm{CP} 18$ zones were specified. According to Agnini et al. (2014), the CNO4 zone spans the interval from the first occurrence of Sphenolithus distentus to the last occurrence of $S$. praedistentus. As mentioned above, the last occurrence of $S$. praedistentus and the first occurrence of $S$. ciperoensis were not recorded. Therefore, the NP23 zone corresponds to the CNO3 zone and the lower part of $\mathrm{CNO} 4$ or the $\mathrm{CP} 17$ zone and the lower part of CP18. In this study, the abundance of calcareous nannofossils is also suddenly reduced in this biozone, and no nannofossil was recorded at levels between $111.35 \mathrm{~m}$ and $118 \mathrm{~m}$. The lower part of the NP23 zone is defined as Rupelian (32-29.6 Ma) (Gradstein et al. 2012).

\subsection{Biozone in the lower part of the Asmari Formation}

Although calcareous nannofossils were absent from the transition zone of the Pabdeh and Asmari formations, gradually their abundance increased again in the shale of the Asmari Formation during the Chattian. The biozone identified close to the base of the Asmari Formation is the Sphenolithus ciperoensis Zone.

\subsubsection{Sphenolithus ciperoensis Zone (NP25) - The lower part of CNO5/the lower part of CP19b}

The last biozone in the section is the Sphenolithus ciperoensis Zone. It was proposed by Bramlette and Wilcoxon (1967) and emended by Martini (1976). According to Martini (1971), this zone is defined between the last occurrence of Sphenolithus distentus and the last occurrence of Sphenolithus ciperoensis. The nannofossil assemblage of the topmost part of the section includes Braarudosphaera bigelowii, Coccolithus pelagicus, Cyclicargolithus floridanus, Pontosphaera enormis, Sphenolithus dissimilis, S. moriformis, and Zygrhablithus bijugatus. The last occurrence of $S$. distentus and the first occurrence of $S$. dissimilis were recorded at 123.5 $\mathrm{m}$, but $S$. ciperoensis was not identified. Therefore, only the lower part of the NP25 zone was determined. The preservation of calcareous nannofossils in this part is moderate to good. Moreover, the lower part of this zone corresponds to the lower part of the CP19b subzone defined by the last occurrence of Sphenolithus distentus (at $123.5 \mathrm{~m}$ ) according to the Okada and Bukry (1980) zonation. Based on Agnini et al. (2014), the CNO5 zone spans the interval from the last occurrence of Sphenolithus praedistentus to the last occurrence of Sphenolithus ciperoensis. At the base of the Asmari Formation, the last occurrence of $S$. predistentus was not recorded. However, based on the last occurrence of $S$. distentus, the lower part of the $\mathrm{CNO} 5$ zone is suggested. The age of this zone is Chattian (late Oligocene).

\section{Discussion}

The present study focuses on two key topics: (1) identification and abundance of calcareous nannofossils, and relevant bio-events; (2) environmental conditions and nutrient controls in the Eocene-Oligocene transition (EOT).

\subsection{Evaluation of calcareous nannofossils and bio-events}

Coccolithophores are the group of marine algae that secretes calcium carbonate crystals inside their cells to build individual coccoliths (Thierstein and Young 2004). This group is sensitive to changes in temperature, light, and nutrient concentration and is therefore widely used in paleoecological and environmental studies (Wade and Bown 2006). Also, they play an important role in the global carbon cycle (Rost and Riebesell 2004). Due to their great diversity and extensive geographical distribution in oceanic environments, coccoliths provide one of the most important fossil components of Cenozoic marine sediments (Bopp et al. 2001; Bown et al. 2004). According to Roth and Thierstein (1972), the preservation of species is highly sensitive to alterations in sediments such as recrystallization and dissolution. In other words, the preservation depends on the degree of etching and 
overgrowth, which provides accurate preservation information (Roth et al. 1970). In the present study, a semiquantitative analysis was carried out throughout the sequence from the late Eocene to the late Oligocene. Here, the calcareous nannofossils are generally common, as well as show good preservation so that many stratigraphic marker species have been recognized, allowing an accurate zonation. However, the diversity of calcareous nannofossils at the transition between the Pabdeh and Asmari formations sharply decreased. In this regard, the present study presents a biostratigraphic framework based on the occurrence of the following taxa: the first occurrences of Cribrocentrum isabellae, Sphenolithus distentus, and the last occurrences of Coccolithus formosus, Cribrocentrum reticulatum, Discoaster saipanensis, Reticulofenestra umbilicus, and Sphenolithus distentus. Species such as Coccolithus pelagicus, Cribrocentrum reticulatum, Cyclicargolithus floridanus, Dictyococcites bisectus, Discoaster deflandrei, Helicosphaera euphratis, Pontosphaera multipora, Reticulofenestra minuta, Reticulofenestra umbilicus, Sphenolithus moriformis, Sphenolithus praedistentus, and Zygrhablithus bijugatus are common in some slides. Discoaster barbadiensis, D. saipanensis, Helicosphaera compacta, Reticulofenestra stavensis, and Sphenolithus pseudoradians are relatively few in numbers. Moreover, Discoaster tanii, Sphenolithus distentus, and Sphenolithus dissimilis are often rare taxa in this study (Fig. 4). Most of the species listed above reflect open marine to shelf conditions (Okada and Bukry 1980; Perch-Nielsen 1985; Bohaty and Zachos 2003; Thierstein and Young 2004; Dunkley Jones et al. 2008; Agnini et al. 2014). In contrast, there are other indicators that indicate a decrease in water depth and stress conditions, including nannofossils such as Braarudosphaera (e.g., Konno et al. 2007).

\subsection{Environmental conditions and nutrient controls}

About 34 million years ago, Earth's climate shifted from relatively greenhouse conditions to icehouse conditions (e.g., Bohaty and Zachos 2003; Dunkley Jones et al. 2008). A diverse range of fossil and sedimentary data change in a characteristic way during the Eocene-Oligocene transition, indicating a period of reorganization of the global climate (Blaj et al. 2009). For this period, calcareous nannofossils are precise ecological indicators that reflect environmental variables, as their distribution was affected by ecological parameters such as temperature and nutrient supply (Bown et al. 2004; Blaj et al. 2009). In fact, nannoplankton distribution pattern is strongly related to surface water-temperature and nutrient availability, which in turn are linked to water circulation. Tropical oceanic environments, which are seasonally stable and support the highest diversity but have few calcareous nannofossil assemblages, indicate oligotrophic (low nutrient) conditions (Kanungo et al. 2017). In contrast, eutrophic (nutrient-rich) conditions that are associated with the continental shelf, support high abundances dominated by only a few species (Andruleit et al. 2003). Moreover, the recovery of hydrocarbons in Paleogene sediments and identification of source rocks, reservoir rocks, and stratigraphic traps have led to a demand for a detailed biostratigraphy of the Eocene-Oligocene interval (Kanungo et al. 2017). During this period, important Eocene-Oligocene genera include Chiasmolithus, Discoaster, Helicosphaera, Sphenolithus, and Reticulofenestra, which provide evidence for climate changes (Coxall and Pearson 2007; Bordiga et al. 2015). Significant changes in the facies near the boundary of the Pabdeh and Asmari formations in the Bid-Zard section are also due to environmental changes. In the present study, dolomitic facies with microbialites formed in the upper part of the Pabdeh Formation in very shallow water at the boundary of the Pabdeh and Asmari formations in the Oligocene (Rupelian). The ideal condition for tufa formation is water temperature, but some studies have shown that tufa also formed under lowered temperature conditions, which are influenced by seasonal temperature fluctuations (Dipova and Doyuran 2006; Kosun 2012). After the formation of microbial tufa in the upper part of the Pabdeh Formation, anhydrite sediments formed at the base of the Asmari Formation. Anhydrite deposits form in warm climates (Dipova and Doyuran 2006). Subsequently, during marine transgression, shales were deposited on the Asmari anhydrite. Therefore, the presence of evaporite deposits between the Pabdeh and Asmari formations indicates a change in climatic conditions with a decrease in the depth of the sedimentary basin. Due to the depth decrease in the late Rupelian, a disconformity was formed between the Pabdeh and Asmari formations. In addition, the existence of a disconformity was confirmed by a red paleosol horizon. The changing conditions also control the nannofossil assemblages at the boundary. In fact, there is a direct relationship between temperature fluctuations and calcareous nannofossil assemblages. According to Bown et al. (2004), cooling reduced the diversity of calcareous nannofossils during the Oligocene. In contrast, increasing productivity is suggested by the occurrence of calcareous nannofossils. For example, Coccolithus pelagicus and Cyclicargolithus floridanus occur in high-productivity eutrophic environments and indicate a marked increase of nutrient concentrations in surface waters during the Oligocene (Dunkley Jones et al. 2008; Villa et al. 2008; Blaj et al. 2009; Shcherbinina 2010). In this study, Cyclicargolithus floridanus increases slightly in abundance up-section and just above the Eocene-Oligocene Transition (EOT). Coccolithus pelagicus, another important component of the 


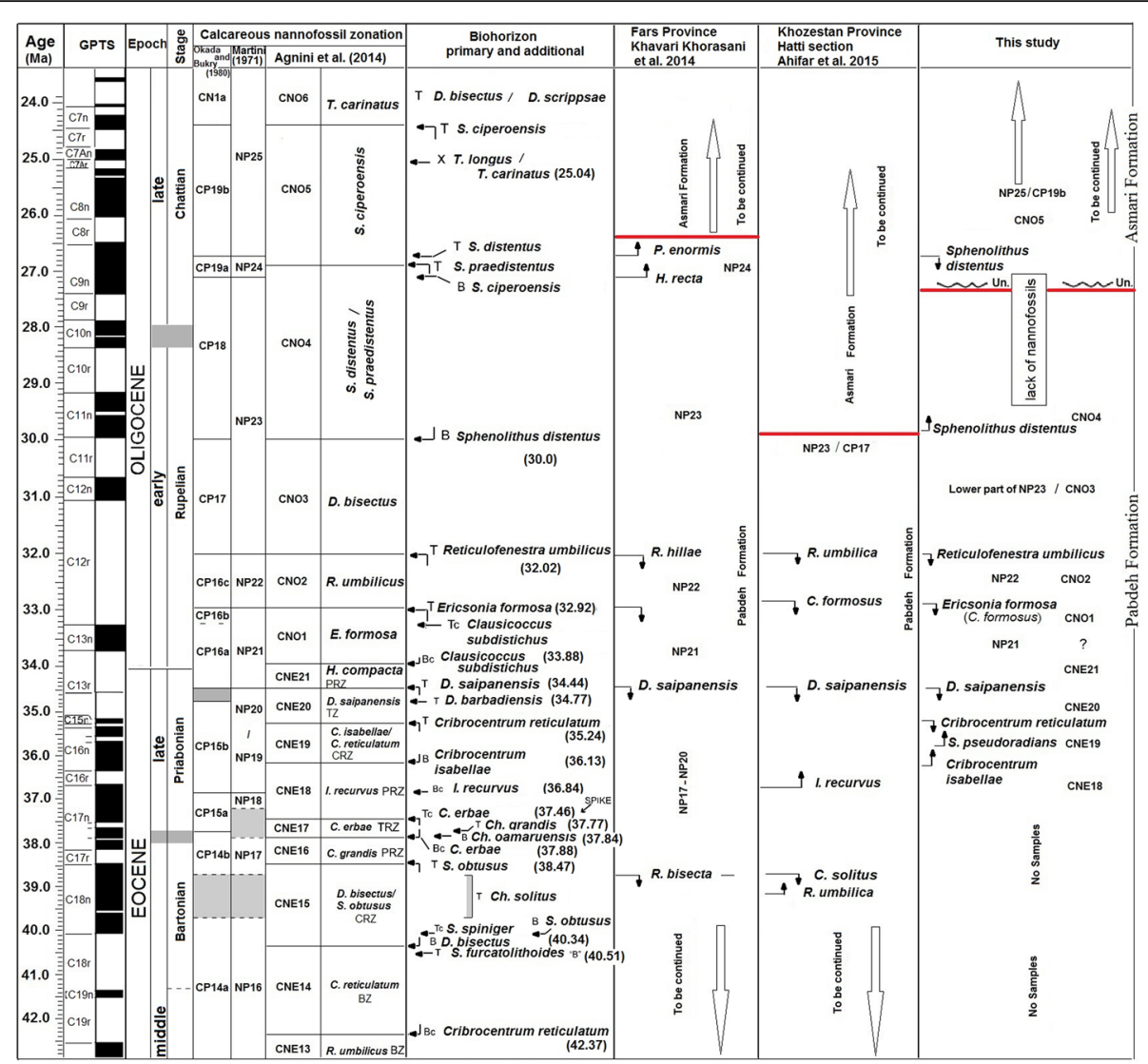

Fig. 6 Comparison of the standard zonation schemes for calcareous nannofossils of the Tethyan realm with the biozonation established in the Bid-Zard section, and the correlation of bio-events in the transition between the Pabdeh and Asmari formations in the Zagros Basin (the red line is the boundary between the Pabdeh and Asmari formations)

nannofossil assemblage (Fig. 4), increases in abundance between $22.29 \mathrm{~m}$ and $60.5 \mathrm{~m}$, above the EOT, and then decreases from $60.5 \mathrm{~m}$ onwards. The presence of Cyclicargolithus floridanus, with an increase in the Rupelian interval, indicates eutrophic conditions and shows that the Oligocene had a cooler climate than the Eocene (Winter et al. 1994; Villa et al. 2008; Oszczypko-Clowes and Żydek 2012). Moreover, temperate water taxa were also identified in the studied section based on the varying abundance of Reticulofenestra umbilica and Dictyococcites bisectus (Villa et al. 2008; Bordiga et al. 2015), among which D. bisectus constitutes a significant part of the assemblages throughout the late Eocene (NP19/NP20 combined zone) to the early Oligocene (the lower part of NP23 zone). In contrast, the abundance of Discoaster species (D. barbadiensis, D. saipanensis, $D$. tanii) decreases below the EOT and never becomes as abundant as in the Priabonian. In addition, taxa such as Braarudosphaera and small Reticulofenestra spp. indicate shallow shelf environments (Kameo 2002; Villa et al. 2008). For example, Braarudosphaera bigelowii, observed in the upper part of the studied section, prefers coastal waters and nutrient-rich environments (Konno et al. 2007). The small Reticulofenestra spp. are eutrophic species, as well as other reticulofenestrids such as Reticulofenestra minuta, and would suggest warm marine conditions (Kameo 2002). Therefore, the abundance of Reticulofenestra minuta is connected with marine nutrient availability at the top of the Pabdeh Formation. Here, the mechanisms for increasing nutrient availability along with decreasing water depth in the Rupelian should be considered. Due to the diversity of species such as Cyclicargolithus, Discoaster, Helicosphaera, Pontosphaera, and Sphenolithus, which are known as very useful ecological indicators, it can be established that the study area was located at low latitudes. Also, helicosphaerids such as Helicosphaera euphratis, common in the Paleogene assemblages, are generally considered to prefer warm to temperate waters and are an indicator for increased nutrient availability (Auer et al. 2014). Thus, this also supports that the basin has been affected by environmental changes.

In the present study, the zonal biostratigraphy based on calcareous nannofossils was also compared with the existing zonations of the Zagros Basin such as the Fars Province (Khavari Khorasani et al. 2014) and the 
Khozestan Province (Ahifar et al. 2015), with the standard Eocene-Oligocene zonation published by PerchNielsen (1985), and with the Paleogene zonations for the Tethyan realm (Agnini et al. 2014) (Fig. 6). The transition between the Pabdeh and Asmari formations indicates different ages in different parts of the Zagros Basin, allowing us to recognize several biozones within the studied time interval. Thus, the upper part of NP23 and NP24 was not recorded in the uppermost part of the Pabdeh Formation during the Oligocene and a disconformity formed at the boundary between the Pabdeh and Asmari formations. In contrast, in some of the previous studies of the Fars Province, a continuous boundary between the Pabdeh and Asmari formations was recorded from the Chattian (NP24) (e.g., Khavari Khorasani et al. 2014), and in some previous studies of the Tang-eAbolhayat section, a continuous trend was recorded from the Priabonian (NP20) to the Chattian (NP24). In the Khozestan Province (Hatti section), Ahifar et al. (2015) also delineated a continuous boundary between the Pabdeh and Asmari formations in the Rupelian (NP23/CP17). No biozone was recorded in the lower part of the Asmari Formation in the previous studies. In the present section, a biostratigraphic gap could be observed at the RupelianChattian boundary, while the lower part of NP25/CP19b was recorded at the base of the Asmari Formation.

\section{Conclusions}

This study focused on the distribution of calcareous nannofossils and environmental variable conditions. As a result, 29 species belonging to 13 genera of calcareous nannofossils were recorded from the Pabdeh and Asmari formations southwest of Izeh in the Zagros Basin of the eastern Tethys domain. Based on evolutionary changes among the calcareous nannofossils, five biozones were recognized according to standard zonation schemes, including the NP19/NP20 combined zone (CP15b/top of CNE18-CNE20) to NP23 (CP18/CNO4) in the upper part of the Pabdeh Formation and the NP25 (CP19b/CNO5) biozone at the base of the Asmari Formation. The different zonations indicate a biostratigraphic gap and no continuous sedimentary record at the Pabdeh/Asmari boundary during the Oligocene, and a lack of nannofossils between the Rupelian and Chattian intervals. However, nannofossils reappeared in the lower part of the Asmari Formation. Biostratigraphic zonations confirm the dating of the studied interval as late Eocene (Priabonian) to late Oligocene (Chattian). Moreover, the presence of a diverse low-latitude nannofossil assemblage in the studied section indicates a tropical climatic. The analysis of calcareous nannofossil assemblages indicates that their abundance and diversity decreased towards the boundary between the Pabdeh and Asmari formations. This decrease is due to environmental changes. Thus, the calcareous nannofossils document relatively warm marine condition, associated with a decreased water depth, which prevailed during the late Eocene-Oligocene of the southwestern Izeh, Zagros Basin, of the eastern Tethys domain.

\section{Abbreviations \\ A: Abundant; C: Common; CCD: Calcite compensation depth: \\ CNE: Calcareous nannofossils Eocene; CNO: Calcareous nannofossils Oligocene; CP: Coccoliths Paleogene; F: Few; FO: First occurrence; FOV: Field of view; LO: Last occurrence; NP: Nanoplankton Paleogene; R: Rare}

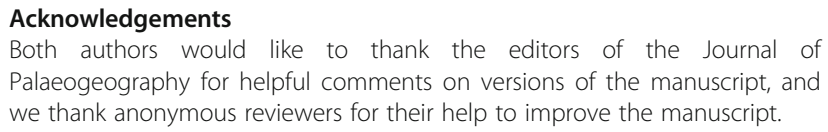

\section{Authors' contributions}

SS analyzed and interpreted the data regarding the calcareous nannofossils and their biostratigraphy, and was a major contributor in writing the manuscript. FJ performed the sampling and preparation of the slides. Both authors read and approved the final manuscript.

\section{Funding}

This study has been supported by Grant 751541 of the Imam Khomeini International University.

\section{Availability of data and materials}

All datasets cited and analyzed in this study are available in this published paper.

\section{Declarations}

\section{Competing interests}

The authors declare that they have no competing interests.

\section{Author details}

${ }^{1}$ Department of Mining, Faculty of Engineering, Imam Khomeini International University, Qazvin, Iran. ${ }^{2}$ Department of Geology, Faculty of Science, University of Birjand, Birjand, Iran.

Received: 10 November 2020 Accepted: 22 April 2021

Published online: 07 May 2021

\section{References}

Aghanabati, A. 2004. Geology of Iran. Tehran: Geological survey of Iran.

Agnini, C., E. Fornaciari, L. Giusberti, P. Grandesso, L. Lanci, V. Luciani, G. Muttoni, H. Palike, D. Rio, D.J.A. Spofforth, and C. Stefani. 2011. Integrated bio-magnetostratigraphy of the Alano section (NE Italy): A proposal for defining the middle-late Eocene boundary. GSA Bulletin 123 (5-6): 841-872. https://doi.org/10.1130/B30158.1.

Agnini, C., E. Fornaciari, I. Raffi, R. Catanzariti, H. Palike, J. Backman, and D. Rio. 2014. Biozonation and biochronology of Paleogene calcareous nannofossils from low and middle latitudes. Newsletters on Stratigraphy 7 (2): 131-181.

Ahifar, A., A. Kani, and H. Amiri Bakhtiar. 2015. Calcareous nannofossil biostratigraphy of Pabdeh formation at Gurpi anticline. Geosciences 24 (95): 107-120.

Alavi, M. 2004. Regional stratigraphy of the Zagros fold-thrust belt of Iran and its proforeland evolution. American Journal of Science 304 (1): 1-20. https://doi.org/10.2475/ajs.304.1.1.

Al-Husseini, M. 2000. Origin of the Arabian plate structures: Amar collision and Najd rift. GeoArabia 5: 527-542.

Amin-Rasouli, H., Y. Lasemi, M. Ghomashi, and S. Zaheri. 2012. The PabdehAsmari boundary facies in Kuh e-Asmari section: Evidence for unconformable Ruplian-Chatian boundary in Iran. Geosciences 21 (83): 59-66.

Amirkhani, A., M. Mirzakhanian, S. Sepahvand, and J. Jalil. 2015. Upper cretaceous petroleum system of northwestern Persian gulf. Iranian Journal of Earth Sciences 7: 153-163.

Amirshahkarami, M., H. Vaziri-Moghaddam, and A. Taheri. 2007. Sedimentary facies and sequence stratigraphy of the Asmari formation at Chaman- 
Bolbol, Zagros Basin, Iran. Journal of Asian Earth Sciences 29 (5-6): 947959. https://doi.org/10.1016/j.jseaes.2006.06.008.

Andruleit, H., S. Stäger, U. Rogalla, and P. Cepek. 2003. Living coccolithophores in the northern Arabian Sea: Ecological tolerances and environmental control. Marine Micropaleontology 49 (1-2): 157-181. https://doi.org/10.1016/S0377-8398(03)00049-5

Auer, G., W.E. Piller, and M. Harzhauser. 2014. High-resolution calcareous nannoplankton palaeoecology as a proxy for small-scale environmental changes in the Early Miocene. Marine Micropaleontology 111: 53-65. https://doi.org/10.1016/j.marmicro.2014.06.005.

Behbahani, R., H. Mohseni, S. Khodabakhshand, and Z. Atashmard. 2010 Depositional environment of the Pabdeh Formation (Paleogene) Elucidated from trace fossils, Zagros Basin, W Iran. Tehran: Proceedings 1st International Applied Geological Congress.

Blaj, T., J. Backman, and I. Raffi. 2009. Late Eocene to Oligocene preservation history and biochronology Pacific Ocean sediments. Rivista Italiana di Paleontologia e Stratigrafia 115 (1): 67-85.

Bohaty, S.M., and J.C. Zachos. 2003. Significant Southern Ocean warming event in the late middle Eocene. Geology 31 (11): 1017-1020. https:// doi.org/10.1130/G19800.1.

Bopp, L., P. Monfray, O. Aumont, J.L. Dufresne, H.L. Treut, G. Madec, L. Terray, and J. C. Orr. 2001. Potential impact of climate change on marine export production. Global Biogeochem Cycles 15 (1): 81-99. https:/doi.org/10.1029/1999GB001256.

Bordenave, M.L., and J.-A. Hegre. 2010. Current distribution of oil and gas fields in the Zagros Fold Belt of Iran and contiguous offshore as the result of the petroleum systems. Geological Society London Special Publications 330 (1): 291-353. https://doi.org/10.1144/SP330.14.

Bordiga, M., J. Henderiks, F. Tori, S. Monechi, R. Fenero, A. Legarda-Lisarri, and E. Thomas. 2015. Microfossil evidence for trophic changes during the EoceneOligocene transition in the South Atlantic (ODP site 1263, Walvis ridge). Climate of the Past 11 (9): 1249-1270. https://doi.org/10.5194/cp-11-1249-2015.

Bown, P.R., J.A. Lees, and J.R. Young. 2004. Calcareous nannoplankton evolution and diversity through time. In Coccolithophores: From Molecular Processes to Global Impact, ed. H.R. Thierstein and J.R. Young, 481-508. Heidelberg: Springer.

Bown, P.R., and J.R. Young. 1998. Technique. In Calcareous Nannofossil biostratigraphy, ed. P.R. Bown, 16-28. Chapman and Hall, London: British Micropalaeontology Society Series. https://doi.org/10.1007/978-94-011-4902-0_2.

Bramlette, M.N., and J.A. Wilcoxon. 1967. Middle tertiary calcareous nannoplankton of the Cipero section, Trinidad, W.I. Tulane Studies in Geology and Paleontology 5 (3): 93-131.

Coxall, H.K., and P. Pearson. 2007. The Eocene-Oligocene transition. In Deep time perspectives on climate change: Marrying the signal from computer models and biological proxies, ed. M. William, A.M. Haywood, F.J. Gregory, and D.N. Schmidt, 351-387. London: Micropalaeontological Society, Geological Society. https://doi.org/10.1144/TMS002.16.

Darvishzadeh, A. 2003. Geology of Iran. Tehran: Amirkabir Publication.

Dipova, N., and V. Doyuran. 2006. Characterization of the Antalya (Turkey) tufa deposits. Carbonates and Evaporites 21 (2): 144-160. https://doi. org/10.1007/BF03175664.

Dunkley Jones, T., P.R. Bown, P.N. Pearson, B.S. Wade, H.K. Coxall, and C. Lear. 2008. Major shifts in calcareous phytoplankton assemblages through the Eocene-Oligocene transition of Tanzania and their implications for low-latitude primary production. Paleoceanography 23 (4): PA4204.

Fornaciari, E., C. Agnini, R. Catanzariti, D. Rio, E.M. Bolla, and E. Valvasoni. 2010. Mid-latitude calcareous nannofossil biostratigraphy and biochronology across the middle to late Eocene transition. Stratigraphy 7 (4): 229-264.

Gholami Fard, A. 2007. Nannostratigraphy of Pabdeh Formation in Gachsaran Oil Field. Tehran: Ph.D. Thesis, University of Shahid Beheshty.

Gradstein, F., J. Ogg, and F. Hilgen. 2012. A geologic time scale. Newsletters on Stratigraphy 45 (2): 171-188. https://doi.org/10.1127/0078-0421/2012/0020.

Hadavi, F., K. Khosrowtehrani, and S. Senemari. 2007. Biostratigraphy of calcareous nannofossils of Gurpi formation in North Gachsaran. Geosciences 64: 14-23.

James, G.A., and J.G. Wynd. 1965. Stratigraphic nomenclature of Iranian oil consortium, agreement area. American Association of Petroleum Geologists, Bulletin 49 (12): 2182-2245.
Kamali, M.R., A. Fathi Mobarakabad, and E. Mohsenian. 2006. Petroleum geochemistry and thermal modeling of Pabdeh formation in Dezful embayment. Journal of Science (University of Tehran) 32 (2): 1-11.

Kameo, K. 2002. Late Pliocene Caribbean surface water dynamics and climatic changes based on calcareous nannofossil records. Palaeogeography, Palaeoclimatology, Palaeoecology 179 (3-4): 211-226. https://doi.org/10.1016/S0031-0182(01)00432-1.

Kanungo, S., J. Young, and G. Skowron. 2017. Microfossils: Calcareous Nannoplankton (Nannofossils). In Encyclopedia of petroleum geoscience, ed. R. Sorkhabi. Cham: Encyclopedia of Earth Sciences Series. Springer https://doi.org/10.1007/978-3-319-02330-4_4-2.

Khavari Khorasani, P., F. Hadavi, and E. Ghaseminejad. 2014. Nannostratigraphy and paleoecology of Pabdeh formation in the northwest of Zagros Basin in llam section. Paleontology 1 (2): 149-164.

Konno, S., N. Harada, H. Narita, and R.W. Jordan. 2007. Living Braarudosphaera bigelowii (gran and Braarud) Deflandre in the Bering Sea. Journal of Nannoplankton Research 29 (2): 78-87.

Kosun, E. 2012. Facies characteristics and depositional environments of quaternary tufa deposits, Antalya, SW Turkey. Carbonates and Evaporites 27 (3-4): 269-289. https://doi.org/10.1007/s13146-012-0089-2.

Lacombe, O., and F. Mouthereau. 2006. Late Cenozoic and modern stress fields in the western Fars (Iran): Implications for the tectonic and kinematic evolution of central Zagros. Tectonics 25: TC1003.

Martini, E. 1971. Standard tertiary and quaternary calcareous nannoplankton zonation. In Second planktonic conference proceedings, Roma 1970, ed. A. Farinacci, 739-785. Rome: Edizioni Tecnoscienza.

Martini, E. 1976. Cretaceous to recent calcareous nannoplankton from the Central Pacific Ocean (DSDP leg 33). Initial Reports of the Deep Sea Drilling Project 33: 383-423.

Motiei, Homayoun. 1994. Geology of Iran, stratigraphy of Zagros. Tehran: Geological Survey of Iran.

Motiei, Homayoun. 1995. Petroleum geology of Zagros. Tehran: Geological Survey of Iran.

Okada, H., and D. Bukry. 1980. Supplementary modification and introduction of code numbers to the low-latitude coccolith biostratigraphic zonation (Bukry, 1973; 1975). Marine Micropaleontology 5: 321-325. https://doi. org/10.1016/0377-8398(80)90016-X.

Oszczypko-Clowes, M., and B. Żydek. 2012. Paleoecology of the upper Eocene-lower Oligocene Malcov Basin based on the calcareous nannofossils: A case study of the Leluchów section (Krynica zone, Magura Nappe, polish outer Carpathians). Geologica Carpathica 63 (2): 149-164. https://doi.org/10.2478/v10096-012-0012-8.

Perch-Nielsen, K. 1985. Cenozoic calcareous Nannofossils. In Plankton stratigraphy, ed. H.M. Bolli, J.B. Saunders, and K. Perch-Nielsen, 427-554. Cambridge: Cambridge University Press.

Popov, S.V., F. Rögl, A.Y. Rozanov, F.F. Steininger, I.G. Shcherba, and M. Kovac. 2004. Lithologic-paleogeographic maps of Paratethys. Courier Forschungsinstitut Senckenberg 250: 1-46.

Rost, B.U., and U. Riebesell. 2004. Coccolithophores and the biological pump: Responses to environmental changes. In Coccolithophores from molecular processes to global impact, ed. H.R. Thierstein and J.R. Okada, 99-125. Heidelberg: Springer.

Roth, P.H., H.E. Franz, and S.W. Wise. 1970. Morphological study of the selected members of the genus Sphenolithus Deflandre (Incerta sedis, tertiary). In Second planktonic conference proceedings, ed. A. Farinacci, 1099-1119. Roma: Edition Tecnoscienza.

Roth, P.H., and H. Thierstein. 1972. Calcareous nannoplankton: Leg 14 of the Deep Sea drilling project. In Initial reports of the Deep Sea drilling project, ed. H.R. Thierstein and H. Okada, 421-485. USA: Government Printing Office

Sadeghi, A., and N. Hadavand Khani. 2010. Biostratigraphy of the Pabdeh formation in the stratigraphic section of Imamzadeh sultan Ibrahim northwest of Izeh City. Iranian Geological Quarterly 15: 81-98.

Senemari, S. 2007. The study of biostratigraphy of planktonic foraminifera and calcareous nannofossils of Gurpi Formation in North of Gachsaran and West Shiraz. Tehran: Ph.D. Thesis, Azad University. 
Senemari, S. 2014. Diversity changes among calcareous nannofossil assemblages across the Paleocene/Eocene boundary in the Zagros (Southwest Iran). Journal of Tethys 2: 45-54.

Senemari, S., and L. Bakhshandeh. 2014. The distribution of calcareous nannofossils in the late Santonian-late Maastrichtian deposits in the southwest of Iran (Khuzestan Province). Arabian Journal of Geoscience 7 (5): 1899-1906. https://doi.org/10.1007/s12517-013-0841-5.

Seyrafian, A. 2000. Microfacies and depositional environment of the Asmar formation at Deh-Dez area (a correlation across central Zagros Basin). Carbonates and Evaporites 5: 121-129.

Shcherbinina, E. 2010. Response of early Paleogene nannofossils to periodically increased nutrient availability in the NE Peri-Tethys. Vienna: EGU General Assembly Conference Abstracts.

Thierstein, H.R., and J.R. Young. 2004. Coccolithophores: From molecular processes to global impact. New York: Springer. https://doi.org/10.1007/ 978-3-662-06278-4.

Vaziri-Moghaddam, H., M. Kimiagari, and A. Taheri. 2006. Depositional environment and sequence stratigraphy of the Oligo-Miocene Asmari formation in SW Iran. Facies 52 (1): 41-51. https://doi.org/10.1007/s1034 7-005-0018-0.

Villa, G., C. Fioroni, L. Pea, S.M. Bohaty, and D. Persico. 2008. Middle Eocenelate Oligocene climate variability: Calcareous nannofossil response at Kerguelen plateau, site 748. Marine Micropaleontology 69 (2): 173-192. https://doi.org/10.1016/j.marmicro.2008.07.006.

Wade, B.S., and P.R. Bown. 2006. Calcareous nannofossils in extreme environments: The Messinian salinity crisis, Polemi Basin, Cyprus. Palaeogeography, Palaeoclimatology, Palaeoecology 233 (3-4): 271-286. https://doi.org/10.1016/j.palaeo.2005.10.007.

Winter, A., R. Jordan, and P. Roth. 1994. Biogeography of living coccolithophores in ocean waters. In Coccolithophores, ed. H. Thierstein and J. Young, 13-37. UK: Cambridge University Press.

\section{Publisher's Note}

Springer Nature remains neutral with regard to jurisdictional claims in published maps and institutional affiliations.

\section{Submit your manuscript to a SpringerOpen ${ }^{\circ}$ journal and benefit from:}

- Convenient online submission

- Rigorous peer review

- Open access: articles freely available online

High visibility within the field

- Retaining the copyright to your article

Submit your next manuscript at $\boldsymbol{\nabla}$ springeropen.com 